Article

\title{
Antibacterial Properties and Effects of Fruit Chilling and Extract Storage on Antioxidant Activity, Total Phenolic and Anthocyanin Content of Four Date Palm (Phoenix dactylifera) Cultivars
}

\author{
Muhammad Azizan Samad ${ }^{1}$, Siti Hajar Hashim ${ }^{1}$, Khanom Simarani ${ }^{1}$ \\ and Jamilah Syafawati Yaacob ${ }^{1,2, *}$ \\ 1 Institute of Biological Sciences, Faculty of Science, University of Malaya, 50603 Kuala Lumpur, Malaysia; \\ azizan_12@siswa.um.edu.my (M.A.S.); hajarhashim93@gmail.com (S.H.H.); hanom_ss@um.edu.my (K.S.) \\ 2 Centre for Research in Biotechnology for Agriculture (CEBAR), Institute of Biological Sciences, \\ Faculty of Science, University of Malaya, 50603 Kuala Lumpur, Malaysia \\ * Correspondence: jamilahsyafawati@um.edu.my; Tel.: +60-379-674-090
}

Academic Editor: Maurizio Battino

Received: 15 January 2016; Accepted: 21 March 2016; Published: 26 March 2016

\begin{abstract}
Phoenix dactylifera or date palm fruits are reported to contain natural compounds that exhibit antioxidant and antibacterial properties. This research aimed to study the effect of fruit chilling at $4{ }^{\circ} \mathrm{C}$ for 8 weeks, extract storage at $-20^{\circ} \mathrm{C}$ for 5 weeks, and extraction solvents (methanol or acetone) on total phenolic content (TPC), antioxidant activity and antibacterial properties of Saudi Arabian P. dactylifera cv Mabroom, Safawi and Ajwa, as well as Iranian P. dactylifera cv Mariami. The storage stability of total anthocyanin content (TAC) was also evaluated, before and after storing the extracts at $-20{ }^{\circ} \mathrm{C}$ and $4{ }^{\circ} \mathrm{C}$ respectively, for 5 weeks. Mariami had the highest TAC $(3.18 \pm 1.40 \mathrm{mg}$ cyd 3-glu/100 g DW) while Mabroom had the lowest TAC (0.54 $\pm 0.15 \mathrm{mg}$ cyd 3-glu/100 g DW). The TAC of all extracts increased after storage. The chilling of date palm fruits for 8 weeks prior to solvent extraction elevated the TPC of all date fruit extracts, except for methanolic extracts of Mabroom and Mariami. All IC 50 values of all cultivars decreased after the fruit chilling treatment. Methanol was a better solvent compared to acetone for the extraction of phenolic compounds in dates. The TPC of all cultivars extracts decreased after 5 weeks of extract storage. $\mathrm{IC}_{50}$ values of all cultivars extracts increased after extract storage except for the methanolic extracts of Safawi and Ajwa. Different cultivars exhibited different antibacterial properties. Only the methanolic extract of Ajwa exhibited antibacterial activity against all four bacteria tested: Staphylococcus aureus, Bacillus cereus, Serratia marcescens and Escherichia coli. These results could be useful to the nutraceutical and pharmaceutical industries in the development of natural compound-based products.
\end{abstract}

Keywords: antioxidant activity; total phenolic content; total anthocyanin content; storage; antibacterial activity; Phoenix dactylifera

\section{Introduction}

Phoenix dactylifera or date palm is a monocotyledon, dioecious plant in the Palmaceae family which inludes about 210 to 220 genera and 1500 to 2500 species [1]. The Food and Agricultural Organization of the United Nations (FAO) estimated that in 2012 Egypt was the largest date palm producer, followed by Iran, Saudi Arabia, Algeria, Iraq, Pakistan, Oman, United Arab Emirates, Tunisia and Libya [2].

Date palm fruits had been assessed for the presence of antioxidant compounds such as anthocyanins, vitamins, carotenoids and phenolic compounds [3,4]. Antibacterial properties were also 
exhibited by date palm extract, which could inhibit the growth of Gram positive and Gram negative bacteria $[5,6]$.

Over the decades there has been an increase in awareness and knowledge among consumers regarding the health benefits of antioxidants. Furthermore, continuous research for antibacterial compounds is a race against the emergence of antibiotic resistant bacteria [7]. These two major issues drive much of the research done on plants to discover their antioxidant compounds and antibacterial properties. Plants are often targeted for this purpose because they are naturally immobilized at a place, which forces them to be adaptable to biotic and abiotic stressors. Bacterial infection is one type of biotic stress that a plant has to overcome. In order to fight against this biotic stress, plants develop resistance mechanisms, which typically involves the synthesis of different metabolites [8].

Therefore, this research was conducted to evaluate the presence of antioxidant compounds and antioxidant activity as well as antibacterial properties in four P. dactylifera cultivars, namely, Mabroom, Safawi, Ajwa and Mariami, which may have the potential to be developed as natural compound-based products by the nutraceutical and pharmaceutical industries.

\section{Results and Discussions}

\subsection{Effect of Solvent Type on Extraction Efficiency}

Methanol and acetone have the same polarity index, i.e., 5.1 [9]. Both solvents were used to examine the extraction of polar compounds, specifically tannins. Date palm fruits are rich in tannins which are reported to be extracted better with absolute methanol [4]. It was also reported that the addition of water to methanol in the extraction of date palm components reduced the extraction efficiency [10]. Therefore, absolute acetone was used as a comparison due its similar polarity index. It was discovered that all methanolic extracts had higher TPC compared to acetone extracts (Figure 1). The mass of extracts yielded from the methanol extraction method ( $67 \%$ to $92 \%$ of $1.0 \mathrm{~g}$ ) was higher compared to the acetone extraction method $(12 \%$ to $31 \%$ of $1.0 \mathrm{~g})$, nevertheless all the $\mathrm{IC}_{50}$ values of the acetone extracts were lower than those of the methanolic extracts, except for the Safawi and Ajwa samples, suggesting that the acetone extracts had more DPPH radical scavenging activity compared to the methanolic extracts.

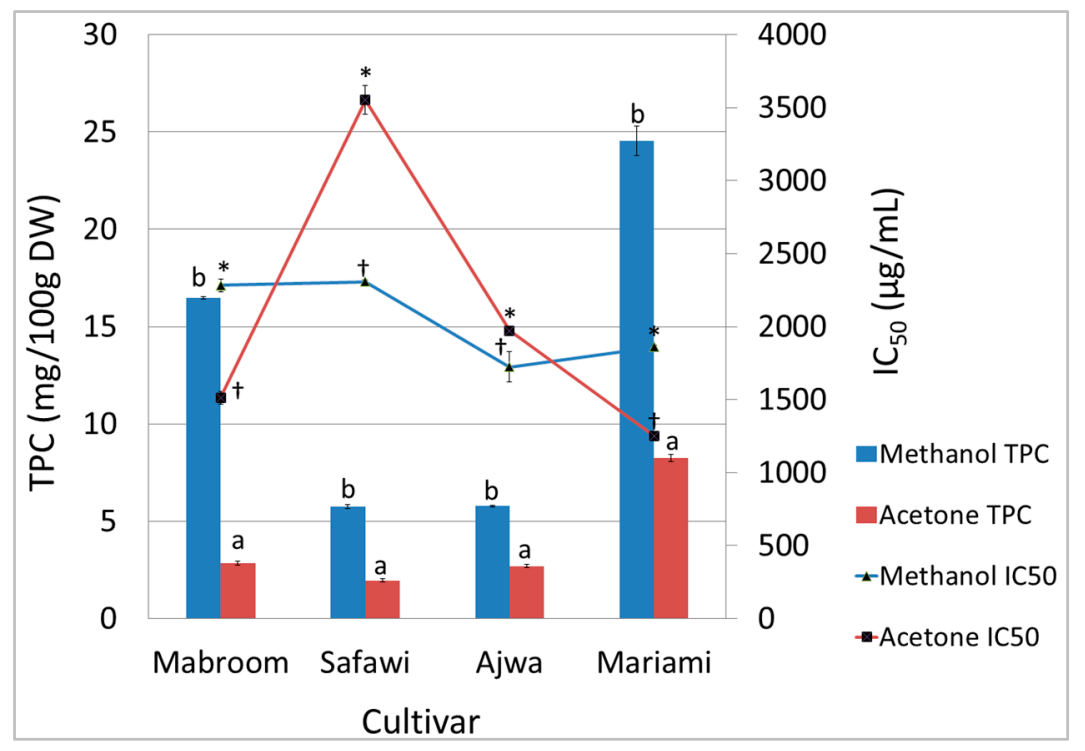

Figure 1. Effect of extraction solvent on TPC (mg GAE/100 g DW) and $\mathrm{IC}_{50}(\mu \mathrm{g} / \mathrm{mL})$ of different $P$. dactylifera cultivars. Values are the mean \pm standard error of a minimum of three samples. The mean with different letters or symbols differs significantly at $p<0.05$ (subject to different cultivars). 
Methanol has higher viscosity and is relatively more polar than acetone, even though they have the same polarity index [9]. The solvent polarity and the solubility of compound to be extracted are two factors that affect the extraction process [11]. Based on the results, it was revealed that methanol could extract the phenolic compounds from date palm fruits better than acetone. These results are supported by previous findings which showed that acetone did not perform well in phenolic compound extraction compared to methanol [12,13]. The efficiency of the phenolic compound extraction by methanol and acetone might also be different depending on the plant species [14]. Other studies showed that methanol was also efficient in extracting certain compounds such as catechin, epicatechin and epigallocatechin $[15,16]$. Even if absolute methanol and acetone could extract the same phenolic compounds, the efficiency of extraction of different phenolic compounds could vary [17], thus affecting the TPC as a whole. It was reported in previous works that acetone could also extract antioxidant enzymes such as peroxidase and catalase $[18,19]$ while methanol could extract polyphenol oxidase which could oxidize phenolic compounds [20,21]. The presence of antioxidant enzymes such as catalase in the acetone extracts might also function as the scavengers of the DPPH radicals [22]. Thus, in short, the solvents used might not just extract phenolic compounds but also other compounds such as oxidative or antioxidant enzymes which could also be responsible for a decrease or increase in the antioxidant activities in the methanolic and acetone extracts of the different date palm cultivars.

\subsection{Effect of Fruit Chilling Prior to Extraction}

In this study, the effect of fruit chilling (at $4{ }^{\circ} \mathrm{C}$ for 8 weeks) prior to extraction on the total phenolic content (TPC) and DPPH scavenging activity of methanolic and acetone extracts of four different P. dactylifera cultivars were investigated. Based on Table 1, it could be observed that the TPC of all date fruit extracts were elevated after fruit chilling, except for the methanolic extracts of Mabroom and Mariami. The TPC of Mabroom, Safawi, Ajwa and Mariami acetone extracts increased by 180.35\%, $217.86 \%, 56.51 \%$ and $59.64 \%$ respectively, after 8 weeks of fruit chilling. Meanwhile, the TPC of Safawi and Ajwa methanolic extracts had increased by $23.61 \%$ and $133.74 \%$, respectively. On the other hand, the methanolic extracts of Mabroom and Mariami showed a decrease in TPC after 8 weeks of fruit chilling, with a TPC loss of $37.62 \%$ and $90.38 \%$, respectively.

Table 1. Effects of fruit chilling at $4{ }^{\circ} \mathrm{C}$ prior to extraction on the total phenolic content, TPC (mg GAE/100 $\mathrm{g} \mathrm{DW}$ ) in fruits of four different $P$. dactylifera cultivars were extracted using different solvents.

\begin{tabular}{cccc}
\hline \multirow{2}{*}{ Cultivar } & \multirow{2}{*}{ Solvent } & \multicolumn{2}{c}{ TPC (mg GAE/ 100 g DW) } \\
\cline { 3 - 4 } & & Week 0 & Week 8 \\
\hline \multirow{2}{*}{ Mabroom } & Methanol & $16.48 \pm 0.07^{\mathrm{b}}$ & $10.28 \pm 0.04^{\mathrm{a}}$ \\
& Acetone & $2.85 \pm 0.11^{\mathrm{a}}$ & $7.99 \pm 0.36^{\mathrm{b}}$ \\
\hline \multirow{2}{*}{ Safawi } & Methanol & $5.76 \pm 0.10^{\mathrm{a}}$ & $7.12 \pm 0.02^{\mathrm{b}}$ \\
& Acetone & $1.96 \pm 0.07^{\mathrm{a}}$ & $6.23 \pm 0.00^{\mathrm{b}}$ \\
\hline \multirow{2}{*}{ Ajwa } & Methanol & $5.78 \pm 0.03^{\mathrm{a}}$ & $13.51 \pm 0.12^{\mathrm{b}}$ \\
& Acetone & $2.69 \pm 0.08^{\mathrm{a}}$ & $4.21 \pm 0.02^{\mathrm{b}}$ \\
\hline \multirow{2}{*}{ Mariami } & Methanol & $24.53 \pm 0.74^{\mathrm{b}}$ & $2.36 \pm 0.11^{\mathrm{a}}$ \\
& Acetone & $8.25 \pm 0.20^{\mathrm{a}}$ & $13.17 \pm 0.36^{\mathrm{b}}$ \\
\hline
\end{tabular}

Values are the mean \pm standard error of a minimum of three samples. The mean with different letters in a row differed significantly at $p<0.05$.

The effect of fruit chilling on DPPH radical scavenging activities of the four different $P$. dactylifera cultivars was also investigated. The results were interpreted as $50 \%$ inhibition concentration $\left(\mathrm{IC}_{50}\right)$ in $\mu \mathrm{g} / \mathrm{mL}$, as shown in Table 2. Interestingly, all $\mathrm{IC}_{50}$ values decreased after the fruit chilling treatment, and yet, the decrement was not significantly different in the methanolic extract of Safawi. The decrease 
in $\mathrm{IC}_{50}$ values was an indication that the extract concentration required to inhibit DPPH radical scavenging activity by $50 \%$ was lowered, indicating an increase in the antioxidant capacity. Ajwa fruits extracted with acetone showed the highest decrease among all extracts after 8 weeks of chilling at $4{ }^{\circ} \mathrm{C}$.

Table 2. Effect of fruit chilling at $4{ }^{\circ} \mathrm{C}$ prior to extraction on $\mathrm{IC}_{50}(\mu \mathrm{g} / \mathrm{mL})$ in fruits of four P. dactylifera cultivars extracted using different solvents.

\begin{tabular}{cccc}
\hline \multirow{2}{*}{ Cultivar } & \multirow{2}{*}{ Solvent } & \multicolumn{2}{c}{ IC $_{50}(\mu \mathrm{g} / \mathrm{mL})$} \\
\cline { 3 - 4 } & & Week 0 & Week 8 \\
\hline \multirow{2}{*}{ Mabroom } & Methanol & $2282.88 \pm 43.19^{\mathrm{c}}$ & $1379.24 \pm 40.75^{\mathrm{b}}$ \\
& Acetone & $1512.68 \pm 42.76^{\mathrm{c}}$ & $1323.17 \pm 74.63^{\mathrm{b}}$ \\
\hline \multirow{2}{*}{ Safawi } & Methanol & $2306.90 \pm 12.07^{\mathrm{b}}$ & $2179.67 \pm 157.36^{\mathrm{b}}$ \\
& Acetone & $3552.33 \pm 98.38^{\mathrm{c}}$ & $451.67 \pm 11.67^{\mathrm{b}}$ \\
\hline \multirow{2}{*}{ Ajwa } & Methanol & $1722.09 \pm 103.75^{\mathrm{c}}$ & $1377.33 \pm 66.74^{\mathrm{b}}$ \\
& Acetone & $1970.97 \pm 2.65^{\mathrm{c}}$ & $53.80 \pm 1.31^{\mathrm{a}}$ \\
\hline \multirow{2}{*}{ Mariami } & Methanol & $1860.76 \pm 9.79^{\mathrm{c}}$ & $1188.95 \pm 2.79^{\mathrm{b}}$ \\
& Acetone & $1250.79 \pm 17.06^{\mathrm{c}}$ & $130.77 \pm 2.62^{\mathrm{b}}$ \\
\hline
\end{tabular}

Values are the mean \pm standard error of a minimum of three samples. The mean with different letters in a row differed significantly at $p<0.05$.

Our results showed lower TPC values in the four tested cultivars (Mabroom, Safawi, Ajwa and Mariami) compared to the TPC of Tunisian Allig, Deglet Nour and Bejo varieties [23]. Factors such as cultivars, geographic origins, growing conditions and soil type may affect the TPC in dates [24]. The variation of proanthocyanins and phenolic compounds may explain the difference of the phenolic content in different date palm fruit varieties [25]. Besides that, Mabroom, Safawi and Ajwa dates originate from Medina, Saudi Arabia whereas Mariami dates originate from Iran. This might also contribute to the differences in the TPC as the agricultural practices of each country may be different. The increase in the TPC after fruit chilling may be due to the activity of phenylalanine ammonia lyase which is stimulated by the ethylene produced in the fruits as a result of chilling [26,27]. It is the key enzyme in the preliminary step for the channeling of carbon from primary metabolism to phenylpropanoid secondary metabolism [28]. The elevation in the activity of phenylalanine ammonia lyase, followed by the rise in ethylene production was observed in citrus fruit subjected to chilling injury [29].

On the other hand, the decrease of the phenolic content may be due to the action of glycosidase, phenolase and polyphenol oxidase activity [18,30]. The biosynthesis of these enzymes was suggested to be stimulated by ethylene [18]. The activities of these enzymes were also dependent on the $\mathrm{pH}$, temperature, salts and inhibitors [18]. In date palm, flavans and chlorogenic acids were susceptible to phenolase as ripening proceeds, which caused a decrease in insoluble tannins [31]. The activity of polyphenol oxidase might also be elevated due to chilling injury [32]. Other than enzymatic reactions, the TPC decrease could also be the result of non-enzymatic reactions such as the oxidation of ascorbic acid to dehydroascorbic acid which produces hydrogen peroxide as a by-product and which may adversely affect the phenolic compounds due to their biochemical properties as antioxidants [33]. The production of ascorbic acid and dehydroascorbic acid could increase due to chilling stress [34]. Moreover, oxygen radicals were also suggested to be induced during chilling stress [34,35]. In this study, only the methanolic extracts of Mabroom and Mariami showed a reduction in TPC after 8 weeks of fruit chilling. These may be due to the activity of polyphenol oxidase in the methanolic extracts, which became elevated due to the chilling injury.

Based on the results, all $\mathrm{IC}_{50}$ values observed in this study were lower compared to that reported by Kchaou et al. [36], which ranged from 16,700 to $46,790 \mu \mathrm{g} / \mathrm{mL}$, depending on the varieties. The antioxidant activity of all extracts had been elevated and most apparent elevation was observed in the acetone extract of Ajwa. This result was in agreement with Kondo et al., where blueberries stored 
at low temperature for 3 months showed an increment in antioxidant activity [37]. Similarly, the antioxidant capacity of banana skin also increased during storage [38]. The TPC of the extracts before and after fruit chilling was also plotted against the reciprocal of $\mathrm{IC}_{50}\left(1 / \mathrm{IC}_{50}\right)$, and showed poor linear correlations $\left(R^{2}=0.0028\right.$ and 0.0449 , before and after chilling treatment, respectively). This indicates that the antioxidant activity was not solely dependent on the amount of TPC but also on the level of polymerization and hydroxylation of the phenolic compounds [39,40]. It is known that phenolic compounds were not the sole constituent of the extracts. Other compounds such as enzymes could also be present. It was mentioned that peroxidase could be extracted by using acetone [18], and its presence is stimulated during chilling stress. It was reported that other antioxidant enzymes such as superoxide dismutase, guaiacol peroxidase and ascorbate peroxidase also had elevated activity during chilling stress [34]. Furthermore, in this study, during the Folin-Ciocalteau's assay for phenolic content, the samples were incubated at room temperature, therefore causing elevation of temperature in the samples. According to Shen et al. [34], levels of antioxidant compounds such as ascorbic acid and reduced glutathione increase after rewarming occurs. The temperature elevation in the samples may contribute to an increase in antioxidant compound levels in the extracts, thus increasing the antioxidant activities, as observed in this study.

\subsection{Effect of Extract Storage on Stability of TPC and Antioxidant Potential}

In this study, the total phenolic content in chilled fruits of four different P. dactylifera cultivars, extracted using methanol and acetone was compared, before and after 5 weeks of extract storage at $-20^{\circ} \mathrm{C}$. Based on Figure 2, the TPC of both methanolic and acetone extracts showed significant reductions after being stored at $-20^{\circ} \mathrm{C}$ for 5 weeks, and the TPC of the methanolic extracts of Mabroom, Safawi, Ajwa and Mariami decreased by $64.01 \%, 78.79 \%, 94.45 \%$ and $24.58 \%$, respectively. On the other hand, $94.12 \%, 39.17 \%, 71.50 \%$ and $89.98 \%$ decreases were observed in the TPC of acetone extracts of Mabroom, Safawi, Ajwa and Mariami respectively. Lower decrease percentages may indicate a more stable extract. Hence, among the methanolic extracts, Mariami date extract was the most stable, whereas among the acetone extracts, Safawi date extract was the most stable.

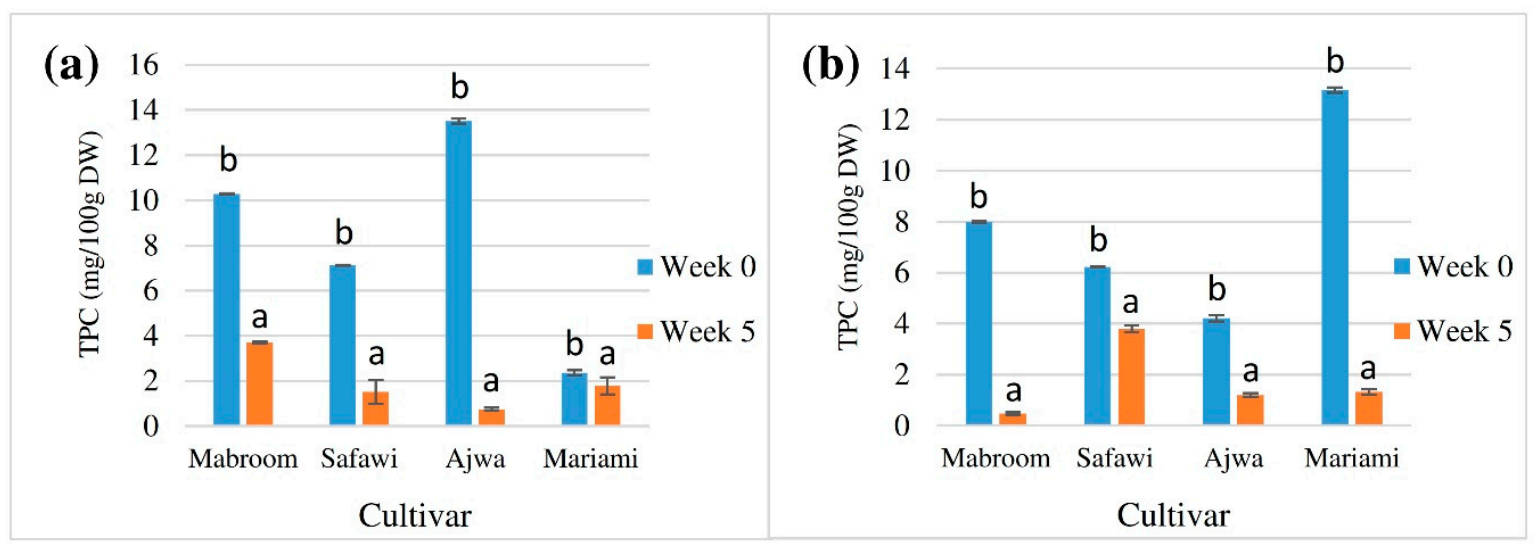

Figure 2. Effect of extract storage at $-20^{\circ} \mathrm{C}$ on TPC (mg GAE/100 g DW) of four different $P$. dactylifera cultivars, extracted using different solvents; (a) extraction using methanol, (b) extraction using acetone. Values are the mean \pm standard error of a minimum of three samples. The means with different letters on a bar differed significantly at $p<0.05$ (subject to different cultivars).

It was revealed that the TPC of all extracts generally decreased after 5 weeks of storage, parallel to the results reported in previous studies on fruit juices [37,41,42]. In a similar study on acai fruit, which is a relative of date palm, a decrese in phenolic compounds also occurred during juice storage [43], due to decreases in procyanidin and $p$-coumaric acid concentrations, resulting in an overall polyphenolic loss. Klimczak et al. suggested that phenolic compounds such as free and conjugated hydroxycinnamic 
acids in orange juices were also affected during storage [42]. The decrease of phenolic content during frozen storage may be due to the oxidation of the antioxidant compounds [41]. Therefore it could be inferred that the decrease of TPC after extract storage observed in this study may be due to the reduction of the most abundant phenolic constituent in the extract, due to oxidation.

There was a very high correlation between the percentage of DPPH radical scavenging activity and extract concentration, shown by $\mathrm{R}^{2}>0.96$ (data not shown). $\mathrm{IC}_{50}$ values of extracts of all cultivars increased after extract storage, except for the methanolic extracts of Safawi and Ajwa (Table 3). As for Mabroom and Mariami, the increase in $\mathrm{IC}_{50}$ values in the methanolic extracts was not significantly different (Table 3). The elevation of $\mathrm{IC}_{50}$ values indicates a reduction of antioxidant capacity, and vice versa. Methanolic extracts of Safawi and Ajwa also became more reactive against DPPH after 5 weeks of extract storage.

Table 3. Effect of chilled fruits extract storage at $-20{ }^{\circ} \mathrm{C}$ on $\mathrm{IC}_{50}(\mu \mathrm{g} / \mathrm{mL})$ of different $P$. dactylifera extracted using different solvents.

\begin{tabular}{cccc}
\hline \multirow{2}{*}{ Cultivar } & \multirow{2}{*}{ Solvent } & \multicolumn{2}{c}{ IC $_{50}(\mu \mathrm{g} / \mathrm{mL})$} \\
\cline { 3 - 4 } & & Week 0 & Week 5 \\
\hline \multirow{2}{*}{ Mabroom } & Methanol & $1379.24 \pm 40.75^{\mathrm{b}}$ & $1412.74 \pm 47.35^{\mathrm{b}}$ \\
& Acetone & $1323.17 \pm 74.63^{\mathrm{b}}$ & $2476.12 \pm 1.00^{\mathrm{c}}$ \\
\hline \multirow{2}{*}{ Safawi } & Methanol & $2179.67 \pm 157.36^{\mathrm{c}}$ & $152.66 \pm 3.53^{\mathrm{b}}$ \\
& Acetone & $451.67 \pm 11.67^{\mathrm{b}}$ & $577.20 \pm 51.95^{\mathrm{c}}$ \\
\hline \multirow{2}{*}{ Ajwa } & Methanol & $1377.33 \pm 66.74^{\mathrm{c}}$ & $1121.67 \pm 27.98^{\mathrm{b}}$ \\
& Acetone & $53.80 \pm 1.31^{\mathrm{a}}$ & $1385.50 \pm 8.89^{\mathrm{c}}$ \\
\hline \multirow{2}{*}{ Mariami } & Methanol & $1188.95 \pm 2.79^{\mathrm{b}}$ & $1190.28 \pm 56.00^{\mathrm{b}}$ \\
& Acetone & $130.77 \pm 2.62^{\mathrm{b}}$ & $2280.08 \pm 5.33^{\mathrm{c}}$ \\
\hline
\end{tabular}

Values are the mean \pm standard error of a minimum of three samples. The means with different letters in a row differed significantly at $p<0.05$.

Based on the results, methanolic extracts were observed to be more stable compared to acetone extracts, as a lower increase in $\mathrm{IC}_{50}$ values was observed in methanolic extracts compared to acetone ones. The decrease in the antioxidant activity of extracts after extract storage was in agreement with previous studies [42,43]. Liolios et al. also reported similar observations, where higher antioxidant activity was not associated with higher amount of TPC [44]. There was a poor linear correlation between TPC and $1 / \mathrm{IC}_{50}$ before $\left(\mathrm{R}^{2}=0.0449\right)$ and after $\left(\mathrm{R}^{2}=0.0011\right)$ extract storage. The reactivity of phenols is dependent on the level of methylation, methoxylation or other group substituents since phenols act as proton donors [45]. The oxidation of ascorbic acid within the extracts might also result in the lower antioxidant activity, as previously reported [46]. The presence of stable compounds upon storage such as flavanones may also affect the stability of the extracts [42]. Other than that, different samples may contain different antioxidant compounds, thus, the behavior and reactivity of these compounds are also different. These reasoning may explain the elevation or loss of antioxidant capacity shown by the date fruit extracts.

\subsection{Total Anthocyanin Content (TAC) and Effect of Extract Storage on Anthocyanin Stability}

In this study, the anthocyanin content in the fruits of four different $P$. dactylifera cultivars was also compared. As shown in Figure 3, Mariami fruits had the highest initial anthocyanin content $(3.18 \pm 1.40 \mathrm{mg}$ cyd 3-glu/100 g DW) while Mabroom had the lowest $(0.54 \pm 0.15 \mathrm{mg}$ cyd 3-glu/100 g DW). Excess and unused fruit extracts were also stored at $-20{ }^{\circ} \mathrm{C}$ and $4{ }^{\circ} \mathrm{C}$ for 5 weeks, and compared for its anthocyanin stability. The results are shown in Figure 3. After 5 weeks of extract storage at $-20{ }^{\circ} \mathrm{C}$ and $4{ }^{\circ} \mathrm{C}$, interestingly, the anthocyanin content in all samples increased tremendously, in both treatments. The analysis of results indicated that the anthocyanin content in 
Mabroom and Mariami fruit extracts increased more when the extracts were stored at $4{ }^{\circ} \mathrm{C}$ compared to the storage at $-20^{\circ} \mathrm{C}$, in contrast to Safawi and Ajwa (Figure 3).

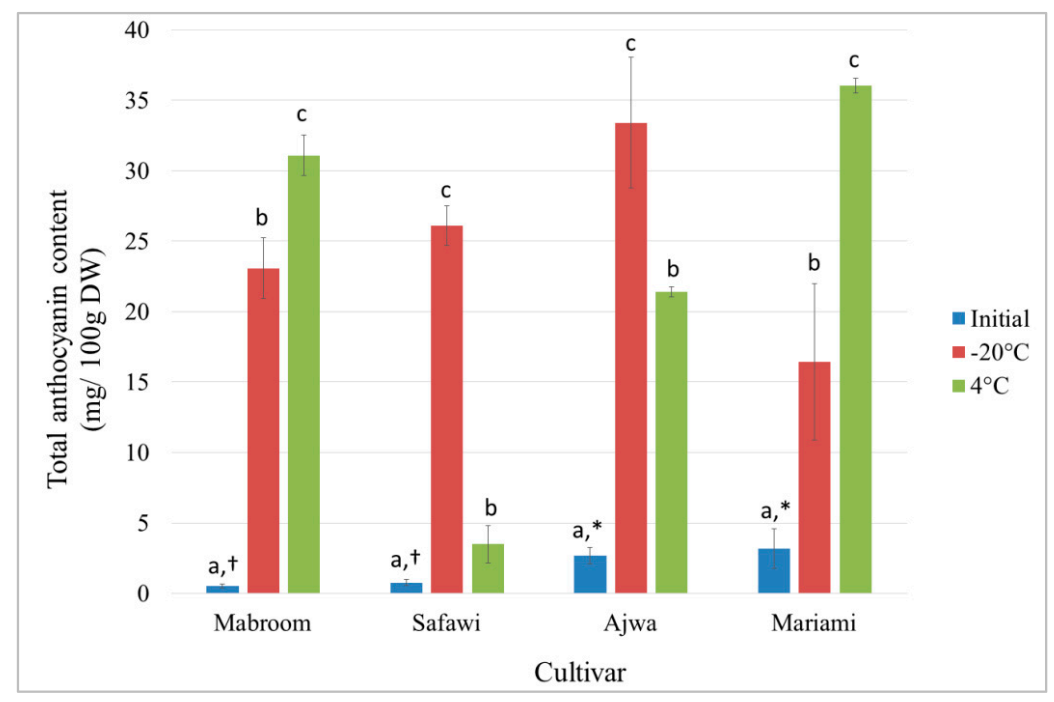

Figure 3. Effect of storage temperature $\left(-20^{\circ} \mathrm{C}\right.$ and $\left.4{ }^{\circ} \mathrm{C}\right)$ on the stability of anthocyanin content in different $P$. dactylifera cultivars, after 5 weeks. Values are the mean \pm standard error of a minimum of three samples. The means with different letters and/or symbols differed significantly at $p<0.05$ (subject to different cultivars).

Al-Farsi et al. discovered that the anthocyanin content in fresh Omani date palm fruits varied depending on variety and it was absent in sun-dried dates due to the damage caused by sunlight [24]. In this study, the fruits were freeze-dried instead of sun-dried to prevent the degradation of anthocyanins. Although the anthocyanin content in the extracts increased after 5 weeks of extract storage at $-20^{\circ} \mathrm{C}$ and $4^{\circ} \mathrm{C}$, the anthocyanin content in date palm extracts was still relatively lower compared to fruits rich in anthocyanin such as blackberries (1004.9 mg cyd 3-glu/100 g DW) [47], blueberries (580-1370 mg cyd 3-glu/100 g DW) [48], and black raspberry (540-559 mg cyd 3-glu/100 g DW) [49].

The increase in the anthocyanin content after extract storage may be associated with the decrease of extract $\mathrm{pH}$ after storage (Table A1). At pH 1.0 to 3.1, where anthocyanin compounds such as cyanidin 3-glucoside and petanin mainly exist in flavylium cationic form at least $90 \%$ of the colour was stable for 60 days [50]. It may also be due to the presence of colour-stable proanthocyanins which resulted from the reaction of anthocyanins with other compounds such as cinnamic acid, which is prevalent in date palm fruits [51,52]. Other than that, the tremendous increase of anthocyanins in the extract could also be due to self-association, co-pigmentation and acylation [33]. It was established that the high concentration of anthocyanins did not follow Beer's Law [53] because of the association and stacking effect of anthocyanins at high concentration which enhances the absorbance. In other words, hypothetically, these factors masked the real amount of anthocyanin content in the extracts. At lower temperature, the chemical reactions between anthocyanins and cinnamic acids commonly are slower [54]. Nevertheless, hypothetically, the degree of association and stacking effect of anthocyanins may cause the significant observed differences between the increases of anthocyanin content between the date palm varieties after extract storage.

\subsection{Antibacterial Activity}

Based on Table 4, none of the $100 \mathrm{mg} / \mathrm{mL}$ acetone extracts exhibited any antibacterial activity. The lowest concentration of methanolic extract of Mabroom that could inhibit S. aureus growth was $100 \mathrm{mg} / \mathrm{mL}$. The lowest concentration of methanolic extract of Ajwa and Mariami that could inhibit S. aureus growth was $300 \mathrm{mg} / \mathrm{mL}$. This indicated that the methanolic extract of Mabroom was more 
potent against $S$. aureus than methanolic extract of Ajwa and Mariami. The lowest concentration of methanolic extracts of Mabrooom and Mariami that could inhibit B. cereus growth was $500 \mathrm{mg} / \mathrm{mL}$ while methanolic extracts of Safawi and Ajwa could inhibit B. cereus growth at $400 \mathrm{mg} / \mathrm{mL}$. There was no inhibition zone observed for E. coli for the methanolic extracts of Mabroom and Mariami. However, Safawi and Ajwa showed similar antibacterial activity against E. coli. None of the extracts exhibited antibacterial activity against $S$. marcescens except for the methanol extract of Ajwa whereby $300 \mathrm{mg} / \mathrm{mL}$ was the lowest concentration observed that could inhibit $S$. marcescens growth.

Table 4. Effect of different treatments on the diameter $(\mathrm{mm})$ of the inhibition zone of different bacteria.

\begin{tabular}{|c|c|c|c|c|c|c|}
\hline \multirow{2}{*}{ Gram } & \multirow{2}{*}{ Bacteria } & \multirow{2}{*}{ Treatment } & \multicolumn{4}{|c|}{ Diameter of Inhibition Zone (mm) } \\
\hline & & & Mabroom & Safawi & Ajwa & Mariami \\
\hline \multirow{16}{*}{ Positive } & \multirow{8}{*}{ S. aureus } & $\mathrm{dH}_{2} \mathrm{O}$ & ND & ND & ND & ND \\
\hline & & Amp & $15.8 \pm 0.3^{\mathrm{d}}$ & $6.3 \pm 0.3^{\mathrm{a}}$ & $6.5 \pm 0.3^{c}$ & $16.3 \pm 0.9^{c}$ \\
\hline & & A & 0 & 0 & 0 & 0 \\
\hline & & Ma & $0.3 \pm 0.3^{\mathrm{a}}$ & 0 & 0 & 0 \\
\hline & & $\mathrm{Mb}$ & $3.3 \pm 1.7^{b}$ & 0 & 0 & 0 \\
\hline & & $\mathrm{Mc}$ & $4.2 \pm 0.8^{b}$ & 0 & $1.0 \pm 0.3^{\mathrm{a}}$ & $2.7 \pm 2.7^{\mathrm{a}}$ \\
\hline & & $\mathrm{Md}$ & $10.0 \pm 0.6^{\mathrm{c}}$ & 0 & $2.0 \pm 0.7^{\mathrm{a}}$ & $9.5 \pm 0.3^{b}$ \\
\hline & & $\mathrm{Me}$ & $15.3 \pm 0.3^{d}$ & 0 & $4.0 \pm 1.5^{\mathrm{b}}$ & $17.5 \pm 0.3^{c}$ \\
\hline & \multirow{8}{*}{ B. cereus } & $\mathrm{dH}_{2} \mathrm{O}$ & ND & ND & ND & ND \\
\hline & & Amp & $7.3 \pm 0.3^{\mathrm{a}}$ & $9.0 \pm 0.5^{b}$ & $6.8 \pm 0.6^{b}$ & $6.7 \pm 0.3^{\mathrm{a}}$ \\
\hline & & A & 0 & 0 & 0 & 0 \\
\hline & & Ma & 0 & 0 & 0 & 0 \\
\hline & & $\mathrm{Mb}$ & 0 & 0 & 0 & 0 \\
\hline & & Mc & 0 & 0 & 0 & 0 \\
\hline & & $\mathrm{Md}$ & 0 & $1.3 \pm 0.6^{\mathrm{a}}$ & $1.0 \pm 0.3^{\mathrm{a}}$ & 0 \\
\hline & & $\mathrm{Me}$ & $13.5 \pm 1.5^{b}$ & $1.3 \pm 0.6^{\mathrm{a}}$ & $2.0 \pm 0.7^{\mathrm{a}}$ & $5.0 \pm 5.0^{\mathrm{a}}$ \\
\hline \multirow{15}{*}{ Negative } & \multirow{8}{*}{ E. coli } & $\mathrm{dH}_{2} \mathrm{O}$ & ND & ND & ND & ND \\
\hline & & Tet & $11.0 \pm 1.7$ & $5.7 \pm 0.7^{b}$ & $7.3 \pm 0.3^{b}$ & $10.7 \pm 1.2$ \\
\hline & & A & 0 & 0 & 0 & 0 \\
\hline & & $\mathrm{Ma}$ & 0 & 0 & 0 & 0 \\
\hline & & $\mathrm{Mb}$ & 0 & 0 & 0 & 0 \\
\hline & & Mc & 0 & 0 & 0 & 0 \\
\hline & & $\mathrm{Md}$ & 0 & $1.0 \pm 0.0^{\mathrm{a}}$ & $1.0 \pm 0.3^{\mathrm{a}}$ & 0 \\
\hline & & $\mathrm{Me}$ & 0 & $1.0 \pm 0.3^{\mathrm{a}}$ & $1.0 \pm 0.3^{\mathrm{a}}$ & 0 \\
\hline & \multirow{7}{*}{ S. marcescens } & $\mathrm{dH}_{2} \mathrm{O}$ & ND & ND & ND & ND \\
\hline & & Tet & $10.0 \pm 0.0$ & $8.3 \pm 0.9^{a}$ & $12.7 \pm 1.5^{b}$ & $15.7 \pm 9.1$ \\
\hline & & A & 0 & 0 & 0 & 0 \\
\hline & & $\mathrm{Ma}$ & 0 & 0 & 0 & 0 \\
\hline & & $\mathrm{Mb}$ & 0 & 0 & 0 & 0 \\
\hline & & Mc & 0 & 0 & $3.0 \pm 0.0^{\mathrm{a}}$ & 0 \\
\hline & & Md & 0 & 0 & $5.5 \pm 0.3^{\mathrm{a}}$ & 0 \\
\hline
\end{tabular}

Values are the mean \pm standard error of a minimum of three samples. The mean with different letters in a column differed significantly at $p<0.05$ (subject to different bacteria). $\mathrm{dH}_{2} \mathrm{O}$ : distilled water, Amp: $100 \mathrm{mg} / \mathrm{mL}$ ampicillin, Tet: $30 \mu \mathrm{g} /$ disc tetracycline, A: $100 \mathrm{mg} / \mathrm{mL}$ acetone extract, Ma: $100 \mathrm{mg} / \mathrm{mL}$ methanolic extract, $\mathrm{Mb}: 200 \mathrm{mg} / \mathrm{mL}$ methanolic extract, Mc: $300 \mathrm{mg} / \mathrm{mL}$ methanolic extract, Md: $400 \mathrm{mg} / \mathrm{mL}$ methanolic extract, Me: $500 \mathrm{mg} / \mathrm{mL}$ methanolic extract, ND: not detected.

The antibacterial properties of date palm fruit have been proven by various studies $[5,55,56]$. Based on the results (Table 4), different cultivars possessed different antibacterial property. Ajwa exhibits antibacterial activity against all four bacteria, Mabroom and Mariami did not exhibit any antibacterial activity against Gram negative bacteria, while Safawi did not exhibit antibacterial activity against $S$. marcescens. Shakiba et al. reported that methanolic extracts of Mazafati cultivar could not inhibit the growth of E. coli PTCC 1270, E. coli PTCC 1399 and S. marcescens [57]. However, the extract was able to inhibit the growth of E. coli PTCC 1330 [57]. This shows that the antibacterial 
properties of the methanolic extract of date palm could also possibly be selective against certain strain of bacteria. Other published reports also showed that the methanolic extract of date varieties such as Mosaifah, Ruthana, Sukkari, Nabtet Ali, Medjool and Rushodia also exhibited antibacterial activity against E. coli [5]. As for S. marcescens, it had been discovered that $P$. dactylifera (date palm) in Kuwait was susceptible to this bacteria and it caused bacterial pink rot on the plant inflorescence [58]. This showed that the date palm could not either protect itself against $S$. marcescens or it did not produce the compounds that could fight against infection from this bacterium due to its pathogenic properties. Hence, this was probably the reason for the absence of antibacterial activity against $S$. marcescens for Mabroom, Safawi and Mariami.

The presence of antimicrobial properties in date palm was most probably due to the presence of antioxidant compounds, phenolic compounds, tannins, alkaloids, flavonoids and steroids. All of these compounds had been proven to be able to inhibit the growth of microorganisms and fight against bacterial infection [56]. These compounds may act individually as biological active compound or provide a synergistic effect to achieve the antibacterial properties [56].

\section{Materials and Methods}

\subsection{Plant Material}

Mabroom, Safawi, Ajwa and Mariami dates $(500 \mathrm{~g})$ were purchased from Mercu Cita Manufacturing Sdn. Bhd. (Mahnaz Food) Shah Alam, Selangor, Malaysia (3.044290, 101.552069). Mabroom, Safawi and Ajwa dates were from Medina, Saudi Arabia while Mariami dates were from Iran. Information regarding the cultivars and origin were known based on the information supplied by the supplier. Deseeded date fruits $(200 \mathrm{~g})$ of were freeze-dried using a Labconco freeze dryer (Labconco, Kansas City, MO, USA) at $-50^{\circ} \mathrm{C}$. The freeze-dried dates were macerated, transferred into air-tight jars wrapped with aluminium foil and stored at $4{ }^{\circ} \mathrm{C}$. For fruit chilling treatment, the date fruits stored at $4{ }^{\circ} \mathrm{C}$ for 8 weeks were used.

\subsection{Extraction and Quantification of Bioactive Compounds}

\subsubsection{Determination of Total Phenolic Content (TPC)}

The extraction process was conducted as described in previous studies [59,60]. Macerated freeze-dried date fruits $(1.0 \mathrm{~g})$ were subjected to solvent extraction using $99.8 \%$ methanol or $99.5 \%$ acetone $(30 \mathrm{~mL})$. The extractions were conducted separately under dark conditions, at room temperature for seven days. Next, the solution was centrifuged at $9000 \mathrm{rpm}$ at $25^{\circ} \mathrm{C}$ for $5 \mathrm{~min}$, from which the supernatant was collected, and then transferred into the evaporating flask of a Rotavapor ${ }^{\circledR}$ R-3 (Büchi Labortechnik AG, Flawil, Switzerland) to evaporate the excess solvent. The concentration of the solvent-free extract was adjusted to $20 \mathrm{mg} / \mathrm{mL}$ using $99.8 \%$ methanol before being used in the quantification of TPC. In this study, the TPC in date fruits before and after fruit chilling at $4{ }^{\circ} \mathrm{C}$ for 8 weeks were compared. The effect of extract storage at $-20^{\circ} \mathrm{C}$ for 5 weeks on the TPC of the extract was also investigated.

The total phenolic content assay was conducted based on the method described in previous studies $[61,62]$ with minor modifications. Briefly, $7.5 \%$ aqueous sodium carbonate $(2.5 \mathrm{~mL})$ was added into a test tube, followed by $10 \%$ Folin-Ciocalteau's reagent $(2.5 \mathrm{~mL})$ and the sample $(0.5 \mathrm{~mL})$. The mixture was incubated in the dark for $30 \mathrm{~min}$ at room temperature. Blanks were also prepared by the addition of $99.8 \%$ methanol $(0.5 \mathrm{~mL})$ instead of the sample. As the next step, the absorbance was determined at $765 \mathrm{~nm}$ by using a Lambda $25 \mathrm{UV}$-Vis spectrophotometer (Perkin Elmer ${ }^{\mathrm{TM}}$, Waltham, MA, USA). The TPC was then determined from the standard calibration curve $\left(R^{2}=0.9184\right)$, using gallic acid as standard $(0.001-0.006 \mathrm{mg} / \mathrm{mL})$. The TPC in the extracts was expressed as $\mathrm{mg}$ gallic acid equivalent per $100 \mathrm{~g}$ dry weight (mg GAE/100 g DW). 


\subsubsection{DPPH Radical Scavenging Activity}

The DPPH free radicals scavenging assay was conducted to determine the antioxidant activity of the extracts as previously described [60], with minor modifications. Briefly, DPPH solution (1 mL) and diluted sample $(1 \mathrm{~mL}, 10-1000 \mu \mathrm{g} / \mathrm{mL})$ were mixed and shaken in a test tube. Then, $10 \mu \mathrm{g} / \mathrm{mL}$ extract $(1 \mathrm{~mL})$ was added into the test tube. The mixture was incubated for $30 \mathrm{~min}$ in the dark, at room temperature. The absorbance was read at $517 \mathrm{~nm}$ using a Lambda $25 \mathrm{UV}$-Vis spectrophotometer. The procedure was repeated on ascorbic acid samples of the same concentration $(10-1000 \mu \mathrm{g} / \mathrm{mL})$ as a standard comparison. The control used in this assay was DPPH $(1 \mathrm{~mL})$ added with $99.8 \%$ methanol $(1 \mathrm{~mL})$ in a test tube. The blank used in this assay was $99.8 \%$ methanol $(2 \mathrm{~mL})$. In this study, the DPPH scavenging activity in date fruits before and after fruit chilling at $4{ }^{\circ} \mathrm{C}$ for 8 weeks were compared. The effect of the extract storage at $-20^{\circ} \mathrm{C}$ for 5 weeks on the antioxidant potential of the extract was also investigated. The percentage of the DPPH radical scavenging activity was calculated using the following formula:

$$
\text { DPPH radical scavenging activity }(\%)=\frac{\mathrm{A}_{0}-\mathrm{A}_{1}}{\mathrm{~A}_{0}} \times 100
$$

where, $\mathrm{A}_{0}=$ absorbance of control, $\mathrm{A}_{1}=$ absorbance of sample. The graphs of percentage of DPPH radical scavenging activity against concentration were plotted by performing non-linear regression (third degree polynomial) as previously described [63]. The results were interpreted as $50 \%$ inhibition concentration $\left(\mathrm{IC}_{50}\right)$ values expressed in $\mu \mathrm{g} / \mathrm{mL}$.

\subsubsection{Determination of Total Anthocyanin Content (TAC)}

The extraction process used for the total anthocyanin content (TAC) assay was conducted as previously described $[64,65]$ with some modifications. In this procedure, macerated freeze-dried date fruits $(10.0 \mathrm{~g})$ were subjected to solvent extraction using $99.8 \%$ methanol $(100 \mathrm{~mL})$, conducted in the dark, at room temperature. The crude extract was centrifuged at $9000 \mathrm{rpm}$ at $25^{\circ} \mathrm{C}$ for $5 \mathrm{~min}$ using a Hettich Zentrifugen Universal $32 \mathrm{R}$ (Tuttlingen, Germany). The supernatant was then transferred into clean test tubes wrapped with aluminium foil to be used in a pH-differential analysis. To evaluate the effects of extract storage on anthocyanin stability, the anthocyanin content of the methanolic extracts stored at $-20^{\circ} \mathrm{C}$ and $4{ }^{\circ} \mathrm{C}$ for 5 weeks was compared.

TAC in date palm fruits was determined through the $\mathrm{pH}$ differential method as described by previous research [66] with minor modifications. The $\mathrm{pH}$ of the methanolic date extract was adjusted to $\mathrm{pH} 1.0$ and $\mathrm{pH} 4.5$, and afterwards the absorbance of the samples was measured at 510 and $700 \mathrm{~nm}$. The TAC was calculated using the following formula:

$$
\text { Total anthocyanin content }(\mathrm{mg} \text { cyd 3-glu } / \mathrm{L})=\frac{\mathrm{Ab} \times \mathrm{MW} \times \mathrm{DF} \times 1000}{\varepsilon \times \mathrm{L} \times \mathrm{m}}
$$

where,

$$
\begin{gathered}
\mathrm{Ab}=\left(\mathrm{A}_{510 \mathrm{~nm}}-\mathrm{A}_{700 \mathrm{~nm}}\right) \mathrm{pH1.0}-\left(\mathrm{A}_{510 \mathrm{~nm}}-\mathrm{A}_{700 \mathrm{~nm}}\right) \mathrm{pH} 4.5 \\
\text { Molecular weight }(\mathrm{MW}) \text { of cyd } 3-\mathrm{glu}=449.2 \mathrm{~g} / \mathrm{mol} \\
\text { Extraction coefficient }(\varepsilon)=29,600 \mathrm{~mol} / \mathrm{g} \\
\text { Dilution factor }(\mathrm{DF})=10
\end{gathered}
$$

The results were expressed in $\mathrm{mg}$ cyanidin 3-glucoside/100 $\mathrm{g}$ dry weight (mg cyd 3-glu/100 g DW). 


\subsection{Determination of Antibacterial Activity}

The antibacterial properties in date palm fruits were evaluated using the diffusion disc method [67]. Precultures of Staphylococcus aureus, Bacillus cereus, Escherichia coli and Serratia marcescens were spread on the surface of nutrient agar (NA) using a sterile cotton swab. Sample (10 $\mu \mathrm{L})$ was dropped onto the sterile diffusion disc and then transferred onto the prepared Petri plate containing lawned bacteria. Sterile distilled water was used as negative control. Positive controls used were $100 \mathrm{mg} / \mathrm{mL}$ ampicillin and $30 \mu \mathrm{g} /$ disc tetracycline disc for Gram positive and Gram negative bacteria, respectively. All plates were then incubated in the dark, at $37^{\circ} \mathrm{C}$ for $24 \mathrm{~h}$. Antibacterial activity i.e., the formation of halo (inhibition) zone and the diameter of inhibition zones were measured.

\subsection{Statistical Analysis}

All values were the means of at least three samples. Data were presented as mean \pm standard error. Duncan's test, $t$-test and one-way analysis of variance (ANOVA) were used to compare the results with $\alpha=5 \%$ (SPSS Statistics version 22 for Windows, IBM Inc., Armonk, NY, USA).

\section{Conclusions}

Based on the data analysis, it could be concluded that storage of all four date palm fruit extracts at $4{ }^{\circ} \mathrm{C}$ and $-20{ }^{\circ} \mathrm{C}$ increased the anthocyanin content. The chilling of date palm fruits for 8 weeks prior to solvent extraction increased the TPC of all date fruit extracts except for the methanolic extracts of Mabroom and Mariami cultivars. The antioxidant activity of all four date palm fruit cultivars also increased after fruit chilling treatment. This could be practiced in everyday life to obtain the maximum benefits from date fruits. Different cultivars also exhibited different antibacterial properties.

Acknowledgments: The authors thank the University of Malaya, Malaysia for experimental facilities and financial support (Grant No. BK015-2013) provided.

Author Contributions: J.S.Y., M.A.S. and S.H.H. conceived and designed the experiments; M.A.S. and S.H.H. performed the experiments; J.S.Y., M.A.S., S.H.H. and K.S. analyzed the data; J.S.Y. and K.S. contributed reagents/materials/analysis tools; J.S.Y., M.A.S. and S.H.H. wrote the paper.

Conflicts of Interest: The authors declare no conflict of interest.

\section{Appendix A}

Table A1. The $\mathrm{pH}$ of different $P$. dactylifera cultivars methanolic extracts after 5 weeks of storage at different temperatures.

\begin{tabular}{ccccc}
\hline \multirow{2}{*}{ Treatment (Storage Temperature) } & \multicolumn{4}{c}{$\mathbf{p H}$} \\
\cline { 2 - 5 } & Mabroom & Safawi & Ajwa & Mariami \\
\hline Initial & 6.40 & 6.32 & 6.38 & 6.46 \\
$-20^{\circ} \mathrm{C}$ & 5.86 & 5.75 & 5.83 & 5.96 \\
$4{ }^{\circ} \mathrm{C}$ & 1.69 & 1.76 & 1.59 & 1.62 \\
\hline
\end{tabular}

\section{References}

1. Hadrami, I.E.; Hadrami, A.E. Breeding Date palm. In Breeding Plantation Tree Crops: Tropical Species; Jain, S.M., Priyadarshan, P.M., Eds.; Springer New York: New York, NY, USA, 2009; pp. 191-216.

2. Food and Agriculture Organization of the United Nations (FAO). Crop Production and Trade Data; Available online: http:/ / faostat.fao.org/site/339/default.aspx (accessed on 15 January 2016).

3. Eid, N.M.S.; Al-Awadi, B.; Vauzour, D.; Oruna-Concha, M.J.; Spencer, J.P.E. Effect of cultivar type and ripening on the polyphenol content of date palm fruit. J. Agric. Food Chem. 2013, 61, 2453-2460. [CrossRef] [PubMed] 
4. Amira, E.; Behija, S.E.; Beligh, M.; Lamia, L.; Manel, I.; Mohamed, H.; Lotfi, A. Effects of the ripening stage on phenolic profile, phytochemical composition and antioxidant activity of date palm fruit. J. Agric. Food Chem. 2012, 60, 10896-10902. [CrossRef] [PubMed]

5. Al-Daihan, S.; Bhat, R.S. Antibacterial activities of extracts of leaf, fruit, seed and bark of Phoenix dactylifera. Afr. J. Biotechnol. 2012, 11, 10021-10025. [CrossRef]

6. Jassim, S.A.A.; Naji, M.A. In vitro evaluation of the antiviral activity of an extract of date palm (Phoenix dactylifera L.) pits on a pseudomonas phage. Evid.-Based Complement. Altern. Med. 2010, 7, 57-62. [CrossRef] [PubMed]

7. Clemente, J.C.; Pehrsson, E.C.; Blaser, M.J.; Sandhu, K.; Gao, Z.; Wang, B.; Magris, M.; Hidalgo, G.; Contreras, M.; Noya-Alarcon, O.; et al. The microbiome of uncontacted Amerindians. Sci. Adv. 2015, 1, e1500183-e1500183. [CrossRef] [PubMed]

8. Wasternack, C. Jasmonates: An update on biosynthesis, signal transduction and action in plant stress response, growth and development. Ann. Bot. 2007, 100, 681-697. [CrossRef] [PubMed]

9. Sadek, P.C. The HPLC Solvent Guide; Wiley: Hoboken, NJ, USA, 2002.

10. Shams Ardekani, M.R.; Khanavi, M.; Hajimahmoodi, M.; Jahangiri, M.; Hadjiakhoondi, A. Comparison of antioxidant activity and total phenol contents of some date seed varieties from Iran. Iran. J. Pharm. Res. 2010, 9, 141-146. [PubMed]

11. Sulaiman, S.F.; Sajak, A.A.B.; Ooi, K.L.; Seow, E.M. Effect of solvents in extracting polyphenols and antioxidants of selected raw vegetables. J. Food Compos. Anal. 2011, 24, 506-515. [CrossRef]

12. Anokwuru, C.P.; Anyasor, G.N.; Ajibaye, O.; Fakoya, O.; Okebugwu, P. Effect of extraction solvents on phenolic, flavonoid and antioxidant activities of three nigerian medicinal plants. Nat. Sci. 2011, 9, 53-61.

13. Arabshahi-Delouee, S.; Urooj, A. Antioxidant properties of various solvent extracts of mulberry (Morus indica L.) leaves. Food Chem. 2007, 102, 1233-1240. [CrossRef]

14. Koffi, E.; Sea, T.; Dodehe, Y.; Soro, S. Effect of solvent type on extraction of polyphenols from twenty three Ivorian plants. J. Anim. Plant Sci. 2010, 5, 550-558.

15. Kallithraka, S.; Garciaviguera, C.; Bridle, P.; Bakker, J. Survey of solvents for the extraction of grape seed phenolics. Phytochem. Anal. 1995, 6, 265-267. [CrossRef]

16. Yilmaz, Y.; Toledo, R.T. Oxygen radical absorbance capacities of grape/wine industry byproducts and effect of solvent type on extraction of grape seed polyphenols. J. Food Compos. Anal. 2006, 19, 41-48. [CrossRef]

17. Kajdzanoska, M.; Petreska, J.; Stefova, M. Comparison of different extraction solvent mixtures for characterization of phenolic compounds in strawberries. J. Agric. Food Chem. 2011, 59, 5272-5278. [CrossRef] [PubMed]

18. Hislop, E.C.; Hoad, G.V.; Archer, S.A. Fungal Pathogenicity and the Plant's Response; Cutting, C.V., Ed.; Academic Press: Cambridge, MA, USA, 1973; pp. 87-117.

19. Tauber, H.; Petit, E.L. Convenient methods for preparing crystalline catalase from cow liver. J. Biol. Chem. 1952, 195, 703-706. [PubMed]

20. Hong, Y.J.; Tomas-Barberan, F.A.; Kader, A.A.; Mitchell, A.E. The flavonoid glycosides and procyanidin composition of Deglet Noor dates (Phoenix dactylifera). J. Agric. Food Chem. 2006, 54, 2405-2411. [CrossRef] [PubMed]

21. Eid, N.; Enani, S.; Walton, G.; Corona, G.; Costabile, A.; Gibson, G.; Rowland, I.; Spencer, J.P.E. The impact of date palm fruits and their component polyphenols, on gut microbial ecology, bacterial metabolites and colon cancer cell proliferation. J. Nutr. Sci. 2014, 3, 1-9. [CrossRef] [PubMed]

22. Garcia, E.J.; Oldoni, T.L.C.; Alencar, S.M.D.; Reis, A.; Loguercio, A.D.; Grande, R.H.M. Antioxidant activity by DPPH assay of potential solutions to be applied on bleached teeth. Braz. Dent. J. 2012, 23, 22-27. [CrossRef] [PubMed]

23. Kchaou, W.; Abbes, F.; Attia, H.; Besbes, S. In vitro antioxidant activities of three selected dates from Tunisia (Phoenix dactylifera L.). J. Chem. 2014. [CrossRef]

24. Al-Farsi, M.; Alasalvar, C.; Morris, A.; Baron, M.; Shahidi, F. Comparison of antioxidant activity, anthocyanins, carotenoids, and phenolics of three native fresh and sun-dried date (Phoenix dactylifera L.) varieties grown in Oman. J. Agric. Food Chem. 2005, 53, 7592-7599. [CrossRef] [PubMed]

25. Regnaultroger, C.; Hadidane, R.; Biard, J.F.; Boukef, K. High-performance liquid and thin-layer chromatographic determination of phenolic-acids in palm (Phoenix, Dactilifera) products. Food Chem. 1987, 25, 61-71. [CrossRef] 
26. Ritenour, M.A.; Ahrens, M.J.; Saltveit, M.E. Effects of temperature on ethylene-induced phenylalanine ammonia-lyase activity and russet spotting in harvested iceberg lettuce. J. Am. Soc. Hortic. Sci. 1995, 120, $84-87$.

27. Ritenour, M.A.; Saltveit, M.E. Identification of a phenylalanine ammonia-lyase inactivating factor in harvested head lettuce (Lactuca sativa). Physiol. Plant. 1996, 97, 327-331. [CrossRef]

28. Hwang, J.H.; Kim, M.W.; Kang, Y.H. Effects of ethylene and $\mathrm{Ca}^{2+}$ on activity of phenylalanine ammonia-lyase in glucan-treated Daucus carota. J. Plant Biol. 1994, 37, 263-269.

29. MartinezTellez, M.A.; Lafuente, M.T. Effect of high temperature conditioning on ethylene, phenylalanine ammonia-lyase, peroxidase and polyphenol oxidase activities in flavedo of chilled 'Fortune' mandarin fruit. J. Plant Physiol. 1997, 150, 674-678. [CrossRef]

30. Shahidi, F.; Naczk, M. Phenolics in Food and Nutraceuticals; CRC Press: Boca Raton, FL, USA, 2003.

31. Maier, V.P.; Metzler, D.M. Phenolic constituents of the date (Phoenix dactylifera) and their relation to browning. First Int. Congr. Food Sci. Technol. 1964.

32. Stewart, R.J.; Sawyer, B.J.B.; Bucheli, C.S.; Robinson, S.P. Polyphenol oxidase is induced by chilling and wounding in pineapple. Funct. Plant Biol. 2001, 28, 181-191. [CrossRef]

33. He, J. Isolation of Anthocyanin Mixtures from Fruits and Vegetables and Evaluation of Their Stability, Availability and Biotransformation in the Gastrointestinal Tract. Ph.D. Thesis, The Ohio State University, Columbus, OH, USA, 2008.

34. Shen, W.; Nada, K.; Tachibana, S. Effect of cold treatment on enzymic and nonenzymic antioxidant activities in leaves of chilling-tolerant and chilling-sensitive cucumber (Cucumis sativus L.) cultivars. J. Jpn. Soc. Hortic. Sci. 1999, 68, 967-973. [CrossRef]

35. Wise, R.R.; Naylor, A.W. Chilling-enhanced photooxidation-Evidence for the role of singlet oxygen and superoxide in the breakdown of pigments and endogenous antioxidants. Plant Physiol. 1987, 83, 278-282. [CrossRef] [PubMed]

36. Kchaou, W.; Abbes, F.; Blecker, C.; Attia, H.; Besbes, S. Effects of extraction solvents on phenolic contents and antioxidant activities of Tunisian date varieties (Phoenix dactylifera L.). Ind. Crops Prod. 2013, 45, 262-269. [CrossRef]

37. Reque, P.M.; Steffens, R.S.; Jablonski, A.; Flores, S.H.; Rios, A.D.; de Jong, E.V. Cold storage of blueberry (Vaccinium spp.) fruits and juice: Anthocyanin stability and antioxidant activity. J. Food Compos. Anal. 2014, 33, 111-116. [CrossRef]

38. Kondo, S.; Kittikorn, M.; Kanlayanarat, S. Preharvest antioxidant activities of tropical fruit and the effect of low temperature storage on antioxidants and jasmonates. Postharvest Biol. Technol. 2005, 36, 309-318. [CrossRef]

39. Bertoncelj, J.; Dobersek, U.; Jamnik, M.; Golob, T. Evaluation of the phenolic content, antioxidant activity and colour of Slovenian honey. Food Chem. 2007, 105, 822-828. [CrossRef]

40. Elzaawely, A.A.; Xuan, T.D.; Koyama, H.; Tawata, S. Antioxidant activity and contents of essential oil and phenolic compounds in flowers and seeds of Alpinia zerumbet (Pers.) B.L. Burtt. \& R.M. Sm. Food Chem. 2007, 104, 1648-1653.

41. Mirsaeedghazi, H.; Emam-Djomeh, Z.; Ahmadkhaniha, R. Effect of frozen storage on the anthocyanins and phenolic components of pomegranate juice. J. Food Sci. Technol. Mysore 2014, 51, 382-386. [CrossRef] [PubMed]

42. Klimczak, I.; Malecka, M.; Szlachta, M.; Gliszczynska-Swiglo, A. Effect of storage on the content of polyphenols, vitamin $\mathrm{C}$ and the antioxidant activity of orange juices. J. Food Compos. Anal. 2007, 20, 313-322. [CrossRef]

43. Pacheco-Palencia, L.A.; Hawken, P.; Talcott, S.T. Phytochemical, antioxidant and pigment stability of ACAI (Euterpe oleracea Mart.) as affected by clarification, ascorbic acid fortification and storage. Food Res. Int. 2007, 40, 620-628. [CrossRef]

44. Liolios, C.C.; Sotiroudis, G.T.; Chinou, I. Fatty acids, sterols, phenols and antioxidant activity of phoenix theophrasti fruits growing in Crete, Greece. Plant Foods Hum. Nutr. 2008, 64, 52-61. [CrossRef] [PubMed]

45. Hogg, J.S.; Lohmann, D.H.; Russell, K.E. The kinetics of reaction of 2,2-diphenyl-1-picrylhydrazyl with phenols. Can. J. Chem. 1961, 39, 1588-1594. [CrossRef]

46. Miller, N.J.; Diplock, A.T.; Rice-Evans, C.A. Evaluation of the total antioxidant activity as a marker of the deterioration of apple juice on storage. J. Agric. Food Chem. 1995, 43, 1794-1801. [CrossRef] 
47. Patras, A.; Brunton, N.P.; Da Pieve, S.; Butler, F. Impact of high pressure processing on total antioxidant activity, phenolic, ascorbic acid, anthocyanin content and colour of strawberry and blackberry purees. Innov. Food Sci. Emerg. Technol. 2009, 10, 308-313. [CrossRef]

48. Lohachoompol, V.; Mulholland, M.; Srzednicki, G.; Craske, J. Determination of anthocyanins in various cultivars of highbush and rabbiteye blueberries. Food Chem. 2008, 111, 249-254. [CrossRef]

49. Prior, R.L.; Wilkes, S.; Rogers, T.; Khanal, R.C.; Wu, X.; Hager, T.J.; Hager, A.; Howard, L. Dietary black raspberry anthocyanins do not alter development of obesity in mice fed an obesogenic high-fat diet. J. Agric. Food Chem. 2010, 58, 3977-3983. [CrossRef] [PubMed]

50. Fossen, T.; Cabrita, L.; Andersen, O.M. Colour and stability of pure anthocyanins influenced by $\mathrm{pH}$ including the alkaline region. Food Chem. 1998, 63, 435-440. [CrossRef]

51. Al-Farsi, M.A.; Lee, C.Y. Nutritional and functional properties of dates: A review. Crit. Rev. Food Sci. Nutr. 2008, 48, 877-887. [CrossRef] [PubMed]

52. Mansouri, A.; Embarek, G.; Kokkalou, E.; Kefalas, P. Phenolic profile and antioxidant activity of the Algerian ripe date palm fruit (Phoenix dactylifera). Food Chem. 2005, 89, 411-420. [CrossRef]

53. Francis, F.J. Food colorants-Anthocyanins. Crit. Rev. Food Sci. Nutr. 1989, 28, 273-314. [CrossRef] [PubMed]

54. Schwarz, M.; Winterhalter, P. A novel synthetic route to substituted pyranoanthocyanins with unique colour properties. Tetrahedron Lett. 2003, 44, 7583-7587. [CrossRef]

55. Al-Seeni, M.N. Minerals content and antimicrobial efficacy of date extracts against some pathogenic bacteria. Life Sci. J. Acta Zhengzhou Univ. Overseas Ed. 2012, 9, 504-508.

56. Bhat, R.S.; Al-Daihan, S. Antibacterial properties of different cultivars of Phoenix dactylifera L. and their corresponding protein content. Ann. Biol. Res. 2012, 3, 4751-4757.

57. Shakiba, M.; Kariminik, A.; Parsia, P. Antimicrobial activity of different parts of Phoenix dactylifera. Int. J. Mol. Clin. Microbiol. 2011, 1, 107-111.

58. Riaz, M.; Kumar, V.; Mansoury, E.; Al-Kandari, F.; Al-Kandari, E.; Al-Attar, E.; Al-Ameer, F. Pink rot of inflorscence: A new disease of date palm in Kuwait. Mycopathologia 2009, 7, 1-4.

59. Arnous, A.; Makris, D.P.; Kefalas, P. Effect of principal polyphenolic components in relation to antioxidant characteristics of aged red wines. J. Agric. Food Chem. 2001, 49, 5736-5742. [CrossRef] [PubMed]

60. Gawron-Gzella, A.; Dudek-Makuch, M.; Matlawska, I. DPPH radical scavenging activity and phenolic compound content in different leaf extracts from selected blackberry species. Acta Biol. Crac. Ser. Bot. 2012, 54, 32-38. [CrossRef]

61. Singleton, V.L.; Orthofer, R.; Lamuela-Raventós, R.M. Analysis of total phenols and other oxidation substrates and antioxidants by means of folin-ciocalteu reagent. In Methods in Enzymology; Academic Press: Cambridge, MA, USA, 1999; Volume 299, pp. 152-178.

62. Khorasani Esmaeili, A.; Mat Taha, R.; Mohajer, S.; Banisalam, B. Antioxidant activity and total phenolic and flavonoid content of various solvent extracts from in vivo and in vitro grown Trifolium pratense L. (Red Clover). Biomed. Res. Int. 2015, 2015, 11. [CrossRef] [PubMed]

63. Abourashed, E.A. Thin-layer densitometry as an alternative tool in the quantitative evaluation of the free radical scavenging activity of natural antioxidants. Z. Naturforschung Sect. B J. Chem. Sci. 2005, 60, 1212-1218.

64. Lachman, J.; Orsák, M.; Pivec, V. Antioxidant contents and composition in some vegetables and their role in human nutrition. Zahrad. (Hortic. Sci.) 2000, 27, 103-117.

65. Ponmozhi, P.; Geeta, M.; Saravana Kumar, M.; Suganya Devi, P. Extraction of anthocyanin and analyzing its antioxidant properties from Pithecellobium Dulce fruit pericarp. Asian J. Pharm. Clin. Res. 2011, 4, 41-45.

66. Giusti, M.M.; Wrolstad, R.E. Acylated anthocyanins from edible sources and their applications in food systems. Biochem. Eng. J. 2003, 14, 217-225. [CrossRef]

67. Bauer, A.W.; Kirby, W.M.M.; Sherris, J.C.; Turck, M. Antibiotic susceptibility testing by a standardized single disk method. Am. J. Clin. Pathol. 1966, 45, 493-496. [PubMed]

Sample Availability: Samples of the compounds are not available from the authors. 